\title{
Cross-population responses to conspecific chemical alarm cues in wild Trinidadian guppies, Poecilia reticulata: evidence for local conservation of cue production
}

\author{
Grant E. Brown, Chris K. Elvidge, Camille J. Macnaughton, Indar Ramnarine, and \\ Jean-Guy J. Godin
}

\begin{abstract}
Within freshwater fishes, closely related species produce alarm cues that are chemically similar, leading to conserved antipredator responses. Similar conservation trends are predicted for species with geographically isolated populations. Here, we tested this hypothesis with the guppy (Poecilia reticulata Peters, 1859) from two populations within the Aripo River, Trinidad. Free-ranging guppies in the Lower Aripo (high-predation population) exhibited more risk-aversive inspection behaviour towards a fish predator model paired with the alarm cues of guppies collected from the same population versus a river water control. In comparison, when paired with the alarm cues of guppies from the Upper Aripo (lowpredation population), the response was intermediate. In the laboratory, we tested Upper and Lower Aripo guppies to the alarm cues of the same or different Aripo River donors, Quaré River guppies (a high-predation population from a different drainage), or a water control. Both Upper and Lower Aripo River guppies exhibited the highest intensity response to donors from the same population and the lowest intensity response to Quaré River donors, with the response to different Aripo donors being intermediate. Collectively, these results demonstrate a trend of intraspecific conservation of chemical alarm cue production, leading to population-specific responses to conspecific cues.
\end{abstract}

Résumé : Chez les poissons d'eau douce, les espèces fortement apparentées produisent des signaux d'alarme qui se ressemblent chimiquement, ce qui résulte en une conservation des réactions vis-à-vis les prédateurs. Nous prédisons l'existence de tendances conservatrices semblables chez les populations isolées géographiquement. Nous testons ici cette hypothèse chez des guppys (Poecilia reticulata Peters, 1859) de deux populations habitant la rivière Aripo, Trinidad. Les guppys libres dans le cours inférieur de l'Aripo (population à forte prédation) montrent un comportement d'inspection accompagné d'une plus forte aversion au risque en présence d'un modèle de poisson prédateur assorti des signaux d'alarme de guppys provenant de la même population, par comparaison à un témoin d'eau de rivière. En contraste, lorsque le modèle est assorti des signaux d'alarme des guppys du cours supérieur de l'Aripo (population à faible prédation), la réaction est intermédiaire. En laboratoire, nous avons testé des guppys des cours supérieur et inférieur de l'Aripo en réaction à des signaux d'alarme de donneurs de la même ou de l'autre population de l'Aripo, de guppys de la rivière Quaré (une population à forte prédation d'un autre bassin hydrographique) et d'un témoin d'eau. Les guppys, tant du cours supérieur que du cours inférieur de l'Aripo, réagissent de la façon la plus intense aux donneurs de leur propre population; la réaction aux donneurs de la Quaré sont les plus faibles et la réaction aux donneurs de l'autre population de l'Aripo sont intermédiaires. Dans leur ensemble, ces résultats démontrent une tendance à la conservation intraspécifique de la production de signaux d'alarmes chimiques, ce qui mène à des réactions aux signaux conspécifiques qui sont particulières à chaque population.

[Traduit par la Rédaction]

\section{Introduction}

Population specificity of behavioural phenotypes is often attributed to adaptations to local biotic and (or) abiotic conditions (Endler 1995; Foster 1999; Blumstein 2006). Given the intense selection gradients exerted by predators, it is not surprising that a wide range of prey organisms exhibit population-specific responses in predator avoidance strategies
(Endler 1995; Lima and Steury 2005; Blumstein 2006; Herczeg et al. 2009). Population specificity is known to extend to sensitivity towards predation threats (Endler 1995; Owings et al. 2001; Brown et al. 2007; Botham et al. 2008). Such local adaptations, presumably, allow prey organisms to balance the conflicting demands of predator detection and avoidance and a suite of fitness-related activities such as

Received 27 July 2009. Accepted 27 October 2009. Published on the NRC Research Press Web site at cjz.nrc.ca on 15 January 2010.

G.E. Brown, ${ }^{1}$ C.K. Elvidge, and C.J. Macnaughton. Department of Biology, Concordia University, 7141 Sherbrooke Street West, Montréal, QC H4B 1R6, Canada.

I. Ramnarine. Department of Life Sciences, University of the West Indies, St. Augustine, Trinidad and Tobago.

J.-G.J. Godin. Department of Biology, Carleton University, 1125 Colonel By Drive, Ottawa, ON K1S 5B6, Canada.

${ }^{1}$ Corresponding author (e-mail: gbrown@alcor.concordia.ca). 
foraging, courtship, and territorial defence (Lima and Dill 1990; Brown 2003; Lima and Steury 2005).

Within aquatic vertebrate and invertebrate prey, including the Trinidadian guppy (Poecilia reticulata Peters, 1859) (Nordell 1998; Brown and Godin 1999a), damage-released chemical alarm cues are commonly used to assess local predation threats (Chivers and Smith 1998; Kats and Dill 1998; Wisenden and Chivers 2006). These cues are typically released into the water column following mechanical damage to the skin (Chivers and Smith 1998), and thus are an honest and reliable indicator of local predation threat, allowing for dynamic threat-sensitive behavioural decisions (Brown et al. 2006, 2009). As such, there should exist strong selection pressure on conspecific receivers of these cues to respond appropriately (Brown et al. 2003; Kelly et al. 2006; Wisenden and Chivers 2006). The antipredator benefits accruing to receivers who respond appropriately to alarm cues presumably have favoured the evolution of the widespread use of damage-released chemical alarm cues among aquatic prey species (Wisenden and Chivers 2006; Chivers et al. 2007).

Several authors have demonstrated that within taxonomically related groups, the response to heterospecific alarm cues is conserved (Schutz 1956; Brown and Godin 1997; Brown et al. 2001a, 2003; Mirza and Chivers 2001a; Mirza et al. 2001; Leduc et al. 2003). Because closely related species likely produce chemically similar alarm cues (Brown et al. 2001a; 2003), phylogenetically related species likely produce cues that are detected more readily than cues from phylogenetically distant species (Kelly et al. 2006). In fact, it is known that as the taxonomic distance between species increases, the response to the alarm cue of heterospecifics decreases (Kelly et al. 2006). But what about the possibility of intraspecific conservation among geographically isolated conspecifics? Brown and Godin (1999a) suggested that the Trinidadian guppy exhibits population differences in its responses to conspeific chemical alarm cues, akin to the welldocumented cross-species trends. They reported that guppies collected from high-predation sites within the Quaré River exhibited stronger antipredator responses to the alarm cues of sympatric Quaré River guppies than to alarm cues collected from the Marianne River (a low-predation site) guppies. However, guppy populations from the Quaré and Marianne rivers have been genetically isolated for at least 500000 years (Fajen and Breden 1992), sufficient time for reproductive barriers to form and potentially lead to allopatric speciation (Magurran 2005). Thus, it is unclear if the results of Brown and Godin (1999a) are due to differences in ambient fish predation pressure or to geographic isolation between focal populations.

Throughout the natural range of the guppy in Trinidad, distinct populations are commonly separated by barrier waterfalls into high- and low-predation reaches within the same river (Magurran 2005; Crispo et al. 2006). Selection favouring local adaptations should lead to populationspecific differences in phenotypic traits, such as predator avoidance behaviour (e.g., Magurran and Seghers 1990, 1994), body coloration (Endler 1995), life-history traits (e.g., Reznick et al. 2001), and mating behaviour (e.g., Magurran 1998; Kelly et al. 1999). However, recent studies demonstrate that although these isolated guppy subpopulations exhibit divergence in morphological, behavioural, and life-history traits (Magurran 2005), there still exists considerable (downstream) gene flow between them within rivers (Crispo et al. 2006; van Oosterhout et al. 2006). Thus, there likely exists a gradient of genetic diversity, with isolated populations within a river being more genetically similar to one another than to populations in neighbouring rivers belonging to different drainages (Magurran 2005).

It remains unknown, however, to what extent the welldocumented phylogenetic trend in the recognition and response towards heterospecific alarm cue extends to intraspecific differences in alarm cues. We might predict that guppies should exhibit stronger (more intense) antipredator responses to the alarm cues of donor guppies from the same local population than to alarm cues collected from donors of another population within the same river system or a neighbouring drainage (local conservation hypothesis). Such conserved responses to population-specific alarm cues would be based on the chemical similarity of the alarm cue itself. Alternatively, guppies from high-predation populations might be more likely to differentiate among alarm cues from different donor populations than would guppies from lowpredation pressure populations because of the costs associated with antipredator behaviour, which are presumably greater in high-predation than in low-predation habitats (Brown et al. 2009). This "receiver hypothesis" predicts that guppies from low-predation populations should exhibit a strong, generalized response to any conspecific alarm cue. However, a third alternative exists. The original demonstration of population-specific responses to chemical alarm cues in the guppy (Brown and Godin 1999a) was conducted under laboratory conditions. Because laboratory studies can lack ecological relevance (Magurran et al. 1996; Smith 1997; Leduc et al. 2007), it is unknown if this previous finding is merely a laboratory artefact.

We therefore conducted complementary field and laboratory experiments to test the hypothesis that geographically isolated populations of guppies within rivers should exhibit stronger responses to conspecific chemical alarm cues from the same versus different populations. In the field, we presented shoals of free-ranging guppies in the Lower Aripo River with a realistic model of a fish predator that was paired with the alarm cues of either Lower Aripo or Upper Aripo guppies (or a river water control), and quantified their predator inspection behaviour (cf. Dugatkin and Godin 1992) towards the predator model. In the laboratory, we exposed Lower Aripo and Upper Aripo guppies separately to the alarm cues of Lower Aripo, Upper Aripo, or Quaré River guppies (a high-predation population from a neighbouring drainage) or an aged tap water control, and quantified their antipredator responses.

\section{Materials and methods}

\section{Study populations and stimulus collections}

To generate chemical alarm cue stimuli for use in both field and laboratory experiments, we collected female guppies from two locations in the Aripo River and from a single high-predation site of the Quaré River. The Lower Aripo River is characterized as a high-predation site (Magurran 2005), containing several fish species that prey on juvenile and adult guppies, including the pike cichlid (Crenicichla 
alta Eigenmann, 1912), blue acara (Aequidens pulcher (Gill, 1858)), and brown coscorub (Cichlasoma taenia (Bennett, 1831)). In addition, there are several predators that prey on small, juvenile guppies, including Hart's rivulus (Rivulus hartii (Boulenger, 1890)) and the twospot sardine (Astyanax bimaculatus (L., 1758)). The Upper Aripo River is located above a barrier waterfall and contains only Hart's rivulus and a predatory freshwater prawn (Macrobrachium crenulatum Holthuis, 1950), both of which prey only on small, juvenile guppies (Endler and Houde 1995; Magurran 2005). As such, it can be characterized as a low-predation site. The Aripo River drains southwesterly through the Caroni Drainage. The Quaré River drains southeasterly through the Oropuche drainage and contains a fish predator community similar to that of the Lower Aripo River (Brown and Godin 1999a; Magurran 2005), and thus can be considered a highpredation site.

We collected chemical alarm cues from wild-caught Upper Aripo and Lower Aripo guppies for use in our field experiment. In addition, we collected chemical alarm cues from wild-caught Quaré River guppies and guppies from each of the two Aripo River populations, for use in our laboratory experiment. To do so, we sacrificed nongravid females (assessed visually) via cervical dislocation and immediately removed the head and tail (at the caudal peduncle). We then removed all internal visceral tissues and placed the remaining tissues (skin and underlying skeletal muscle) in $100 \mathrm{~mL}$ of aged (dechlorinated) tap water. Tissue samples were then homogenized and filtered through polyester filter floss and diluted to the desired final volume with the addition of aged tap water. Although the specific chemical makeup of the guppy alarm cue is unknown, whole body homogenates do provide a reliable indicator of local predation risk, and thus function as an alarm cue (Brown and Godin 1999a; Brown et al. 2009). We used a total of 72 Lower Aripo guppies (standard length $20.54 \pm 2.46 \mathrm{~mm}$ (mean $\pm \mathrm{SD})$, body depth $5.88 \pm 1.06 \mathrm{~mm}$ (mean $\pm \mathrm{SD})$ ), 45 Upper Aripo guppies (standard length $24.51 \pm 3.96 \mathrm{~mm}$, body length $6.71 \pm 1.42 \mathrm{~mm}$ ), and 10 Quaré River guppies (standard length $27.70 \pm 1.56 \mathrm{~mm}$, body length $7.40 \pm$ $0.84 \mathrm{~mm}$ ). We thus collected a total of $138.60 \mathrm{~cm}^{2}$ (in $1335 \mathrm{~mL}$ ), $114.81 \mathrm{~cm}^{2}$ (in $1105 \mathrm{~mL}$ ), and $27.14 \mathrm{~cm}^{2}$ (in $261 \mathrm{~mL}$ ) of skin/tissue for the Lower Aripo River, Upper Aripo River, and Quaré River populations, respectively. The final concentration of alarm cue solutions were similar to that used by Brown and Godin (1999a). All alarm cue solutions were frozen in $25 \mathrm{~mL}$ aliquots at $-20{ }^{\circ} \mathrm{C}$ until needed.

\section{Field experiment}

To test the hypothesis that wild Trinidadian guppies exhibit stronger predator avoidance responses to the alarm cues of conspecific donors originating from high-predation than low-predation populations, we conducted predator inspection trials in situ in the Lower Aripo River between 16 April and 22 April 2008. We presented free-ranging guppies with a realistic model of a pike cichlid paired with chemical alarm cue collected from Lower Aripo (high predation) or Upper Aripo (low predation) donors or a control of river water. The model was a cast from a mold of a freshly killed pike cichlid (standard length $14 \mathrm{~cm}$ ), which was realistically painted, fitted with glass eyes, and coated with fiberglass resin. Previous studies have shown that free-ranging guppies respond to this model and live fish predators in a similar fashion (Godin 1995; Brown and Godin 1999a).

Observations were conducted from the shoreline of slowflowing pools $(N=16)$ along a $1 \mathrm{~km}$ stretch of the Lower Aripo River. Our study pools were separated by areas of riffles and (or) deep-water pools. The mean $( \pm \mathrm{SD})$ surface area of the pools was approximately $112 \pm 54 \mathrm{~m}^{2}$. We did not measure current velocity, but surface velocity appeared similar across all pools. All observations were made over similar mixed cobble and fine cobble substrates, with $<25 \%$ leaf litter cover. Mean $( \pm \mathrm{SD})$ water depth (measured at the position of model presentation) was $17.95 \pm 4.39 \mathrm{~cm}$.

Prior to a trial, we positioned a $3 \mathrm{~m}$ length of airline tubing (used to present the chemical alarm stimulus), anchored to a rock $(\sim 5 \mathrm{~cm}$ diameter), at least $75 \mathrm{~cm}$ from the pool edge. Once the stimulus injection tube was in place, we positioned the predator model immediately above the terminal end of the tube and waited until at least five guppies were present within a $50 \mathrm{~cm}$ radius of the model to begin the trial. At the onset of the trial, we injected $25 \mathrm{~mL}$ of one of three chemical stimuli (either alarm cues from Upper Aripo donors (different population), alarm cues from Lower Aripo donors (same population), or a river water control) at a rate of $\sim 5 \mathrm{~mL} / \mathrm{min}$. The river water used as a control was collected upstream of the trial location to reduce the likelihood of contamination from previous observations. A trial lasted $5 \mathrm{~min}$, during which we recorded the following: (i) the number of guppies within a $25 \mathrm{~cm}$ radius of the model every $15 \mathrm{~s}$, (ii) the total number of predator inspection visits, (iii) the number of guppies inspecting per visit, (iv) the proportion of inspections directed towards the tail region of the model (i.e., attack cone avoidance; Dugatkin and Godin 1992), (v) the proportion of inspection visits by singletons, and ( $v i$ ) the occurrence of dashing behaviour. Dashing was defined as a sudden burst swimming away from the model over a distance of at least five guppy body lengths. Predator inspection behaviour was defined as a directed, saltatory approach towards the model by a solitary guppy or group of guppies (Dugatkin and Godin 1992; Brown and Godin 1999a, 1999b). Reductions in the frequency or rate of inspection and number of inspectors per visit, and an increased proportion of inspection visits directed away from the head region of the predator, are consistent with risk-aversive predator inspection behaviour (Brown and Godin 1999b). Within each pool $(N=16)$, we conducted three such trials (one for each of the three chemical treatments). To minimize the chance that guppies were exposed to more than one cue within a pool, we always began each trio of trials downstream (moving upstream for each trial) and separated the specific location of each trial by at least $5 \mathrm{~m}$. The order of presentation of the three chemical stimulus treatments was randomized within a pool, and all observations of inspection behaviour were made blind to the chemical treatment. We conducted a total of 16 trials for each of the three chemical treatments (total $N=48$ ).

We tested for an effect of chemical stimulus treatment (Lower Aripo alarm cue, Upper Aripo alarm cue, or river water control) paired with the predator model for each measures of predator inspection behaviour separately using repeated-measures ANOVAs. The repeated-measures AN- 
OVA approach was used to account for the unlikely event that some guppies may have moved between pools on a given test day (cf. Croft et al. 2003). The analysis does not account for movement of guppies between pools. However, movement of individual guppies between pools in Trinidadian streams appears limited (Reznick et al. 1996), thus is likely not a confounding factor. All behavioural variables were normally distributed and had equal variances; therefore, parametric statistics were employed. Planned contrasts were used to test for differences in fish behavioural responses between the three stimulus treatments.

\section{Laboratory experiment}

To test for the effects of ambient predation pressure and population of origin (of both the test fish and the donor fish) on the response to conspecific chemical alarm cues by Trinidadian guppies, we conducted a complementary laboratory experiment (15-21 April 2008). Our focal study populations consisted of female guppies collected from the Upper Aripo River (low-predation pressure) and Lower Aripo River (high-predation pressure). Guppies from each population were separately exposed to $(i)$ chemical alarm cues from conspecific donors of the same population, (ii) alarm cues from donors from the other Aripo River population, (iii) alarm cues from donors collected from the Quaré River (a different drainage), or (iv) an aged tap water control. For both focal populations (Upper and Lower Aripo River), we conducted a total of 15 trials for each of the two Aripo River alarm cue treatments. In addition, for both focal populations, we conducted 14 trials for the Quaré River alarm cue and water controls (total $N=116$ ). Test guppies were exposed to only a single chemical stimulus treatment and were not reused.

Observations were conducted in a series of identical $23 \mathrm{~L}$ glass aquaria filled with $18.5 \mathrm{~L}$ of dechlorinated tap water $\left(\sim 25{ }^{\circ} \mathrm{C}\right)$. Each tank contained a single airstone and an additional $1.5 \mathrm{~m}$ length of airline tubing to allow for the injection of the chemical stimuli without disturbing the focal fish. To facilitate the quantification of area use (see below), we "divided" the tank into three equal horizontal sections by drawing lines along the front and back walls of the test tank. At least $4 \mathrm{~h}$ prior to a trial, we placed shoals of three nongravid (assessed visually) female guppies into a test tank to acclimatize undisturbed.

Each trial consisted of a 5 min prestimulus and a $5 \mathrm{~min}$ poststimulus observation period. Immediately prior to the prestimulus observation period, we withdrew and discarded $60 \mathrm{~mL}$ of tank water through the stimulus injection tube. We then removed and retained an additional $60 \mathrm{~mL}$ of tank water. Following the prestimulus observation, we injected $5 \mathrm{~mL}$ of one of the four chemical stimuli and slowly flushed it into the test tank with the retained tank water. Once the stimulus was injected, we began the 5 min poststimulus injection observation period. During both the prestimulus and poststimulus observation periods, we recorded $(i)$ an index of area use, (ii) a shoaling index, and (iii) the occurrence of dashing and freezing behaviours. Area use was recorded every $15 \mathrm{~s}$ as the position of each guppy within the tank (1, bottom third of the tank; 3 , top third of the tank). Thus, possible area use scores ranged from 3 (all fish near the substrate) to 9 (all fish near the surface). We also recorded a shoaling index every $15 \mathrm{~s}$, which ranged from 1 (no fish within one body length of each other) to 3 (all fish within one body length of each other). Dashing was defined as a sudden burst of apparently disoriented swimming; freezing was defined as the cessation of all movement, with the guppy settling to the substratum for at least $30 \mathrm{~s}$. A reduction in area use and increases in shoaling index, dashing, and freezing are indicative of antipredator responses in the guppy (Brown and Godin 1999a).

We calculated the change in area use and shoaling index between prestimulus and poststimulus observation periods (poststimulus - prestimulus) and used these difference scores as dependent variables in all subsequent analyses. Area use and shoaling index data were normally distributed and homoscedastic; therefore, parametric statistics were employed on these variables. We tested for the effects of focal population and alarm cue donor population using the twoway ANOVA. We tested for the effects of focal population and alarm cue donor populations on the occurrence of dashing and freezing behaviours using the two-factor $G$ test (Sokal and Rohlf 1995).

\section{Results}

\section{Field experiment}

Overall, free-ranging guppies in the high-predation Lower Aripo River responded to a realistic fish predator model paired with the alarm cue of Lower Aripo guppies as being a more risky predation threat than the model paired with river water (Figs. 1A-1F). Interestingly, the antipredator behavioural responses towards the model paired with Upper Aripo guppy alarm cue were intermediate. More specifically, there was a significant difference in the number of guppies observed within a $25 \mathrm{~cm}$ radius of the predator model among the three chemical stimulus treatments $\left(F_{[2,14]}=4.72, P=0.027\right.$; Fig. $\left.1 \mathrm{~A}\right)$, with fewer guppies approaching the predator model when it was paired with conspecific alarm cues than with river water only. Likewise, significantly fewer inspection visits were directed towards the predator model when it was paired with alarm cues than with river water only $\left(F_{[2,14]}=34.48, P<0.001\right.$; Fig. 1B). When we compared the number of inspection visits observed, corrected for the number of guppies present (per capita inspection rate), we still found a significant effect of the chemical stimulus treatment $\left(F_{[2,14]}=13.38, P=0.001\right.$; Fig. 1C). Lower Aripo guppies exposed to the predator model paired with Lower Aripo alarm cues inspected the model in significantly smaller groups $\left(F_{[2,14]}=58.17, P<\right.$ 0.001 ; Fig. 1D) and with a higher proportion of inspections by singletons $\left(F_{[2,14]}=15.91 ; P<0.001\right.$; Fig. $\left.1 \mathrm{E}\right)$ than did guppies exposed to the model paired with either Upper Aripo alarm cues or the river water control. In addition, guppies exposed to either alarm cue stimuli exhibited a significantly greater proportion of total inspections towards the tail of the predator model (i.e., exhibited attack cone avoidance) compared with the river water control $\left(F_{[2,14]}=56.12\right.$, $P<0.001$; Fig. 1F). Finally, we found a significant effect of the alarm stimulus treatment on the occurrence of dashing behaviour, with dashing observed in 16 (100\%) trials with Lower Aripo alarm cues, 11 (68.75\%) trials with Upper 
Fig. 1. Mean ( \pm SE) number of guppies (Poecilia reticulata) present within a $25 \mathrm{~cm}$ radius of a fish predator model (A), total inspection visits towards the model (B), per capita rate of inspection (C), number of inspectors per visit (D), proportion of inspections by singleton guppies (E), and proportion of inspections directed towards the tail of the model (F) for shoals of Lower Aripo River guppies exposed to the predator model paired with alarm cues collected from Lower Aripo or Upper Aripo guppies, or a river water control under natural conditions. $N=16$ per treatment; different letters denote significant differences $(P<0.05)$ based on planned contrasts.
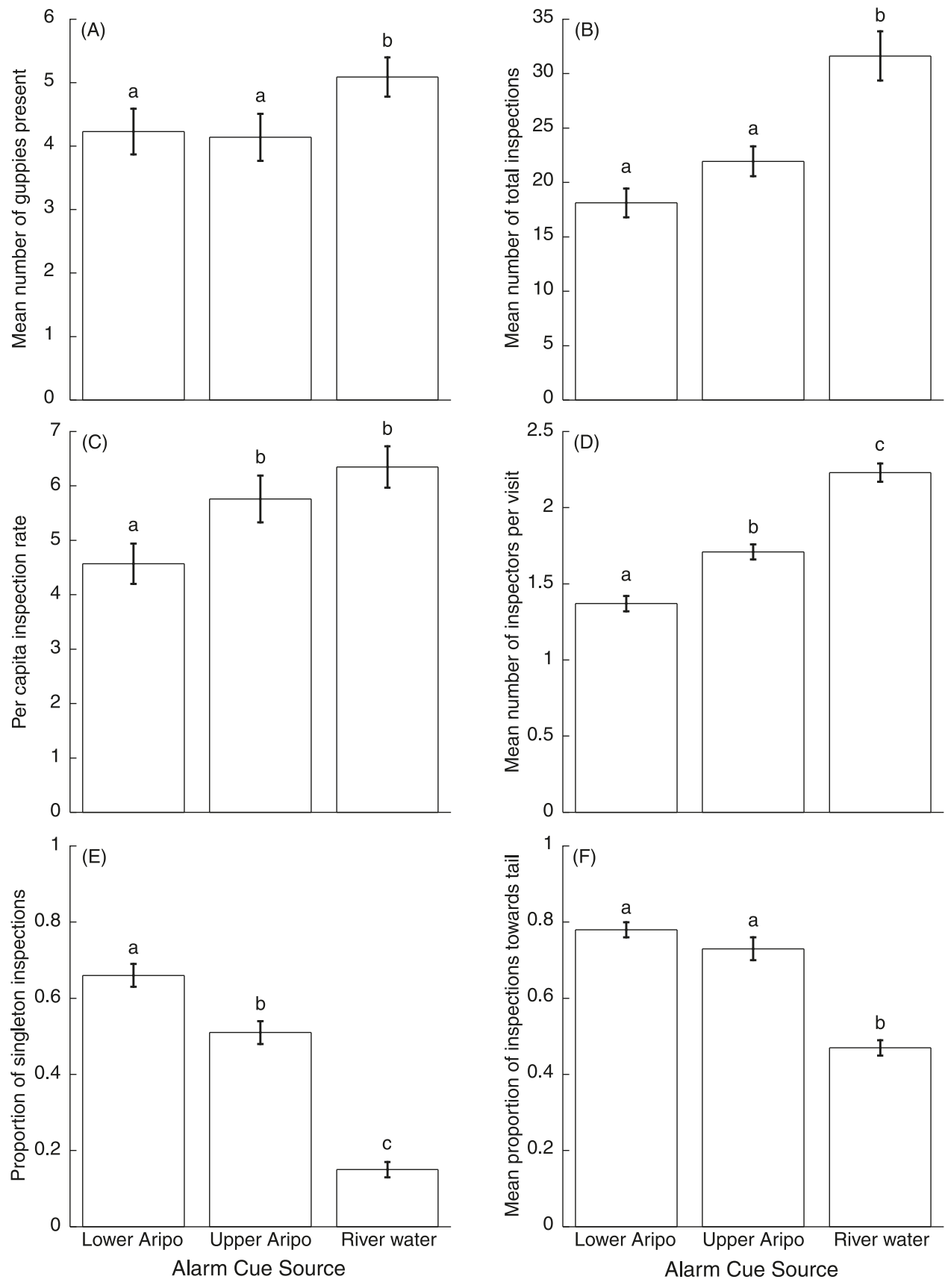

Aripo alarm cues, and only $2(12.5 \%)$ trials with the river water control $\left(\chi_{[2]}^{2}=13.63, P<0.01\right)$.

\section{Laboratory experiment}

Lower Aripo guppies exhibited greater decreases in area use $\left(F_{[1,108]}=4.36, P=0.039\right.$; Fig. $\left.2 \mathrm{~A}\right)$ and greater increases in shoaling index $\left(F_{[1,108]}=4.01, P=0.048\right.$; Fig. 2B) compared with Upper Aripo guppies in response to conspecific chemical alarm cues, irrespective of their source population. Likewise, there was a significant overall effect

of the alarm stimulus treatment for area use $\left(F_{[3,108]}=6.56\right.$, $P<0.001$; Fig. 2A $)$ and shoaling index $\left(F_{[3,108]}=12.86, P<\right.$ 0.001 ; Fig. 2B). For area use, we found no interaction between the two main effects $\left(F_{[3,108]}=1.62, P=0.19\right.$; Fig. 2A). However, for the increase in shoaling index, a significant two-way interaction occurred between focal population and stimulus treatment $\left(F_{[3,108]}=3.49, P=0.018\right.$; Fig. 2B). This interaction is likely owing to the relatively weak responses of both Upper Aripo and Lower Aripo guppies to the alarm cues of Quaré River donors. 
Fig. 2. Mean $( \pm \mathrm{SE})$ change in area use (A) and shoaling index (B) scores and proportion of observations in which dashing (C) or freezing (D) behaviours occurred for Upper Aripo (open bars) and Lower Aripo (shaded bars) guppies (Poecilia reticulata) exposed to alarm cues from the same Aripo population, different Aripo population, Quaré River guppies, or an aged water control. $N=15$ for Aripo same and Aripo different; $N=14$ for each of Quaré River cue treatment and aged water control.
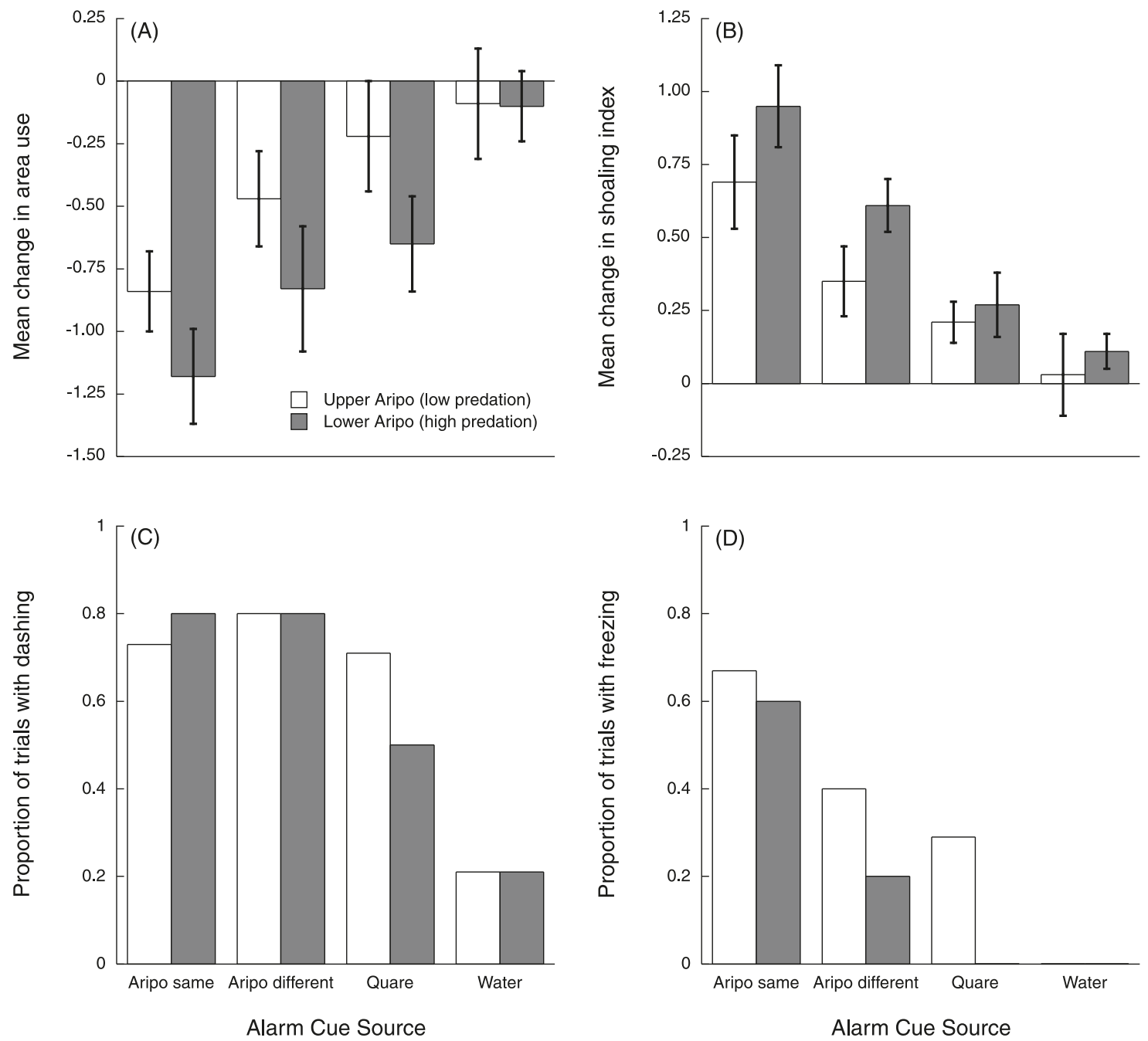

We observed generally similar patterns of behaviour with respect to the occurrence of both dashing and freezing behaviours (Figs. 2C, 2D). Alarm stimulus treatment significantly affected the occurrence (presence versus absence) of dashing $\left(\chi_{[3]}^{2}=88.06, P<0.001\right.$; Fig. $\left.2 \mathrm{C}\right)$. There was no significant effect of focal population $\left(\chi_{[1]}^{2}=0.37, P=0.54\right)$, or an interaction $\left(\chi_{[3]}^{2}=3.57, P=0.31\right)$ between the main effects, on the occurrence of dashing, demonstrating that Upper Aripo and Lower Aripo guppies did not differ in their overall pattern of dashing behaviour (Fig. 2C). In comparison, for the occurrence of freezing behaviour, a significant interaction was observed between the effects of focal population and the alarm stimulus treatment on the frequency of occurrence of freezing behaviour $\left(\chi_{[3]}^{2}=128.4, P<0.001\right.$; Fig. 2D).

Overall, guppies exhibited the strongest antipredator responses when exposed to their own population's chemical alarm cues, irrespective of their provenance. For example, Upper Aripo River (low predation) guppies exhibited the strongest predator avoidance responses to alarm cues from

Upper Aripo conspecifics, followed by Lower Aripo cues, and finally Quaré River cues. Similarly, Lower Aripo River (high predation) guppies exhibited the strongest responses to alarm cues from Lower Aripo conspecifics and the weakest to Quaré River alarm cues, with the responses to Upper Aripo cues being intermediate.

\section{Discussion}

The results of our field experiment demonstrate that Lower Aripo River guppies modified their predator inspection behaviour depending upon the population of origin of the chemical alarm stimulus presented. These guppies exhibited a more risk-aversive inspection pattern when the predator model was paired with alarm cues from Lower Aripo guppies than when the model was paired with a river water control. These results are consistent with our previous laboratory (Brown and Godin 1999b; Brown and Dreier 2002) and field (Brown and Godin 1999a; Brown et al. 2001b) studies of chemically mediated predator inspection behaviour. More interesting is the observation that the pattern of 
inspection behaviour of Lower Aripo guppies in the current study was intermediate when the predator model was paired with the chemical alarm cues of Upper Aripo guppies, suggesting that the alarm cues of a different population were perceived as signaling a lower level of threat locally. This clearly demonstrates that guppies from a high-predation population (Lower Aripo River) can differentiate between chemical alarm cues of donors from the same population versus those from donors of another population. Moreover, our results demonstrate that the differential antipredator responses to the alarm cues of conspecifics originating from different populations is not merely a laboratory artefact.

The results of our current laboratory experiment corroborate and extend the above field-based findings. Both Upper Aripo and Lower Aripo guppies exhibited the strongest antipredator responses to the alarm cues collected from donors of the same population, respectively, and the weakest responses to alarm cues collected from conspecifics in the Quaré River (i.e., from a geographically isolated drainage). Upper Aripo and Lower Aripo guppies both exhibited intermediate responses to the alarm cues of guppies collected from the "other" Aripo population. Combined with our field results, these laboratory data strongly indicate that there exists a high degree of intraspecific conservation of chemical alarm cue production and (or) recognition in the guppy, akin to the well-documented interspecific conservation patterns (Schutz 1956; Brown et al. 2001a, 2003; Mirza and Chivers 2001a; Mirza et al. 2001; Leduc et al. 2003). Presumably, such conservation is the result of some mechanism(s) leading to the production of alarm cues that are chemically more similar within than between populations (cf. Kelly et al. 2006).

At least two nonmutually exclusive mechanisms might account for our results. Despite measurable gene flow between high- and low-predation habitats within rivers (Crispo et al. 2006), genetic similarity is highest within a local population in the Trinidadian guppy (van Oosterhout et al. 2006). Though not yet conclusively demonstrated, it is not unreasonable to suggest that chemical alarm cue production may be under at least partial genetic control. If this is the case, groups with higher genetic similarity (i.e., local populations) may produce chemical alarm cues that are more structurally similar (Kelly et al. 2006). Alternatively, Brown et al. (2004) have shown that diet composition may influence alarm cue production, independent of donor growth or body condition. It is known that the diets of guppies from highpredation and low-predation populations in Trinidad differ (Dussault and Kramer 1981); therefore, habitat-specific food types might influence alarm cue chemistry (Brown et al. 2004; Kelly et al. 2006). Thus, genetic or environmental factors, or likely some interaction between them, may result in alarm cues that are chemically more similar (and more recognizable) within than between populations in the guppy.

Given the demonstrated survival benefits associated with responding to damage-released chemical alarm cues in fishes (Mathis and Smith 1993; Mirza and Chivers 2001b; Leduc et al. 2009) and the mechanism of release, the most parsimonious explanation for the evolution of the predatoravoidance function of "skin extracts" is through the benefits to cue receivers rather than direct selection on cue producers (Chivers et al. 2007). If chemical alarm cues have evolved via this mechanism, one might expect that all receivers should exhibit strong antipredator responses to any conspecific alarm cue, irrespective of its donor source population. However, our results clearly indicate that this is not the case; rather, they suggest population specificity in the pattern of response to chemical alarm cues. Moreover, our findings, that guppies from both high- and low-predation populations within the Aripo River system exhibited the same trend in antipredator response intensity to chemical alarm cues originating from same or different populations (Aripo River same > Aripo River different $>$ Quaré River), are consistent with the prediction of the local conservation hypothesis.

We found no support for the alternative receiver hypothesis. The receiver hypothesis predicts that owing to the elevated costs of predator avoidance behaviour under highpredation risk conditions (Brown et al. 2009), guppies from the Lower Aprio River (high-predation population) should have exhibited a greater degree of population specificity in their responses to chemical alarm cues than guppies from the Upper Aripo River (low-predation population). Such specificity would allow prey to better match the intensity of their predator avoidance behaviour to the level of perceived predation threat (i.e., threat-sensitivity; Brown et al. 2009). Similarly, the receiver hypothesis likewise predicts that under relatively low predation-risk conditions (Upper Aripo River), selection favouring discrimination among alarm cue types would be considerably lower owing to the lower costs of predator avoidance (Brown et al. 2009). Because we found a similar response trend in both focal guppy populations, our results do not support the latter hypothesis.

Previous work has argued that chemical alarm cue conservation within taxonomically related groups would allow heterospecific prey guild members to benefit from the detection of alarm cues independent of prior experience (Smith 1999; Kelly et al. 2006). Our current results extend this model. Conspecific prey, like heterospecific prey guild members, should be expected to maximize the potential antipredator benefits accruing from appropriately responding to some recognizable component of a chemical alarm cue. Genetic and (or) environmental constraints on chemical alarm cue production could result evolutionarily in strong population specificity in the behavioural response of receivers to chemical alarm cues. Such a model does not presuppose any selection acting directly upon cue production, nor does it assume any benefits to cue senders. Our current study lends support to this proposition by experimentally demonstrating intraspecific conservation of receiver antipredator responses to conspecific chemical alarm cues in the Trinidadian guppy. This pattern of local population specificity presumably enhances the detection and avoidance of predation threats. However, the current study is based on a single population pair (Upper Aripo versus Lower Aripo). Additional streams should be compared to test the generality of the current findings.

\section{Acknowledgements}

We thank Darren Croft, Katherine Jones, and Kimberley Hair for assistance in the laboratory and field, as well as David Reznick for discussions on potential guppy populations for our study. We also thank the Director of Fisheries in the 
Trinidadian Ministry of Agriculture, Land and Marine Resources for permission to collect guppies from the Aripo River and Quaré River for use in our study. Financial support was provided by Concordia University and the Natural Sciences and Engineering Research Council of Canada (NSERC) to G.E. Brown and by Carleton University and NSERC to J.-G.J. Godin. All work reported herein was conducted in accordance the guidelines of the Canadian Council on Animal Care and the laws of Canada, and was approved by the Concordia University Animal Research Ethics Committee (protocol No. AREC-2008-BROW).

\section{References}

Blumstein, D.T. 2006. The multipredator hypothesis and the evolutionary persistence of antipredator behavior. Ethology, 112(3): 209-217. doi:10.1111/j.1439-0310.2006.01209.x.

Botham, M.S., Hayward, R.K., Morrell, L.J., Croft, D.P., Ward, J.R., Ramnarine, I., and Krause, J. 2008. Risk-sensitive antipredator behavior in the Trinidadian guppy, Poecilia reticulata. Ecology, 89(11): 3174-3185. doi:10.1890/07-0490.1.

Brown, G.E. 2003. Learning about danger: chemical alarm cues and local risk assessment in prey fishes. Fish Fish. 4(3): 227234. doi:10.1046/j.1467-2979.2003.00132.x.

Brown, G.E., and Dreier, V.M. 2002. Predator inspection behaviour and attack cone avoidance in a characin fish: the effects of predator diet and prey experience. Anim. Behav. 63(6): 1175-1181. doi:10.1006/anbe.2002.3024.

Brown, G.E., and Godin, J.-G.J. 1997. Anti-predator responses to conspecific and heterospecific skin extracts by threespine sticklebacks: alarm pheromones revisited. Behaviour, 134(15-16): 1123-1134. doi:10.1163/156853997X00098.

Brown, G.E., and Godin, J.-G.J. 1999a. Chemical alarm signals in wild Trinidadian guppies (Poecilia reticulata). Can. J. Zool. 77(4): 562-570. doi:10.1139/cjz-77-4-562.

Brown, G.E., and Godin, J.-G.J. 1999b. Who dares, learns: chemical inspection behaviour and acquired predator recognition in a characin fish. Anim. Behav. 57(2): 475-481. doi:10.1006/anbe. 1998.1017. PMID:10049488.

Brown, G.E., Adrian, J.C., Jr., Erikson, J., Kaufman, I.H., and Gershaneck, D. 2001a. Responses to nitrogen oxides by Characiforme fishes suggest evolutionary conservation in ostariophysan alarm pheromones. In Chemical signals in vertebrates. Vol. 9. Edited by A. Marchlewska-Koj, J.J. Lepri, and D. MüllerSchwarze. Plenum Press, New York. pp. 305-312.

Brown, G.E., Golub, J.L., and Plata, D.L. 2001b. Attack cone avoidance during predator inspection visits by wild finescale dace (Phoxinus neogaeus): the effects of predator diet. J. Chem. Ecol. 27(8): 1657-1666. doi:10.1023/A:1010466410152. PMID: 11521403.

Brown, G.E., Adrian, J.C., Jr., Naderi, N.T., Harvey, M.C., and Kelly, J.M. 2003. Nitrogen oxides elicit antipredator responses in juvenile channel catfish, but not in convict cichlids or rainbow trout: conservation of the ostariophysan alarm pheromone. J. Chem. Ecol. 29(8): 1781-1796. doi:10.1023/A:1024894026641. PMID:12956507.

Brown, G.E., Foam, P.E., Cowell, H.E., Guevara-Fiore, P., and Chivers, D.P. 2004. Production of chemical alarm cues in convict cichlids: the effects of diet, body condition and ontogeny. Ann. Zool. Fenn. 41(3): 487-499.

Brown, G.E., Rive, A.C., Ferrari, M.C.O., and Chivers, D.P. 2006. The dynamic nature of antipredator behavior: prey fish integrate threat-sensitive antipredator responses within background levels of predation risk. Behav. Ecol. Sociobiol. 61(1): 9-16. doi:10. 1007/s00265-006-0232-y.

Brown, C., Burgess, F., and Braithwaite, V.A. 2007. Heritable and experiential effects on boldness in a tropical poeciliid. Behav. Ecol. Sociobiol. 62(2): 237-243. doi:10.1007/s00265-007-04583.

Brown, G.E., Macnaughton, C.J., Elvidge, C.K., Ramnarine, I., and Godin, J.-G.J. 2009. Provenance and threat-sensitive predator avoidance patterns in wild-caught Trinidadian guppies. Behav. Ecol. Sociobiol. 63(5): 699-706. doi:10.1007/s00265-008-07034.

Chivers, D.P., and Smith, R.J.F. 1998. Chemical alarm signaling in aquatic predator-prey systems: a review and prospectus. Ecoscience, 5: 338-352.

Chivers, D.P., Wisenden, B.D., Hindman, C.J., Michalak, T.A., Kusch, R.C., Kaminskyj, S.G., Jack, K.L., Ferrari, M.C., Pollock, R.J., Halbgewachs, C.F., Pollock, M.S., Alemadi, S., James, C.T., Savaloja, R.K., Goater, C.P., Corwin, A., Mirza, R.S., Kiesecker, J.M., Brown, G.E., Adrian, J.C., Jr., Krone, P.H., Blaustein, A.R., and Mathis, A. 2007. Epidermal 'alarm substance' cells of fishes maintained by non-alarm functions: possible defence against pathogens, parasites and UVB radiation. Proc. R. Soc. Lond. B Biol. Sci. 274(1625): 2611-2619. doi:10.1098/rspb.2007.0709. PMID:17686729.

Crispo, E., Bentzen, P., Reznick, D.N., Kinnison, M.T., and Hendry, A.P. 2006. The relative influence of natural selection and geography on gene flow in guppies. Mol. Ecol. 15(1): 49-62. doi:10.1111/j.1365-294X.2005.02764.x. PMID:16367829.

Croft, D.P., Albanese, B., Arrowsmith, B.J., Botham, M., Webster, M., and Krause, J. 2003. Sex-biased movement in the guppy (Poecilia reticulata). Oecologia (Berl.), 137(1): 62-68. doi:10. 1007/s00442-003-1268-6.

Dugatkin, L.A., and Godin, J.G.-J. 1992. Predator inspection, shoaling and foraging under predation hazard in the Trinidadian guppy, Poecilia reticulata. Environ. Biol. Fishes, 34(3): 265276. doi:10.1007/BF00004773.

Dussault, G.V., and Kramer, D.L. 1981. Food and feeding behaviour of the guppy, Poecilia reticulata (Pisces: Poeciliidae). Can. J. Zool. 59(4): 684-701. doi:10.1139/z81-098.

Endler, J.A. 1995. Multiple-trait coevolution and environmental gradients in guppies. Trends Ecol. Evol. 10(1): 22-29. doi:10. 1016/S0169-5347(00)88956-9.

Endler, J.A., and Houde, A.E. 1995. Geographic variation in female preferences for male traits in Poecilia reticulata. Evolution, 49(3): 456-468. doi:10.2307/2410270.

Fajen, A., and Breden, F. 1992. Mitochondrial DNA sequence variation among natural populations of the Trinidad guppy, Poecilia reticulata. Evolution, 46(5): 1457-1465. doi:10.2307/ 2409949.

Foster, S.A. 1999. The geography of behaviour: an evolutionary perspective. Trends Ecol. Evol. 14(5): 190-195. doi:10.1016/ S0169-5347(98)01577-8. PMID:10322532.

Godin, J.-G.J. 1995. Predation risk and alternative mating tactics in male Trinidadian guppies (Poecilia reticulata). Oecologia (Berl.), 103(2): 224-229. doi:10.1007/BF00329084.

Herczeg, G., Gonda, A., and Merilä, J. 2009. Predation mediated population divergence in complex behaviour of nine-spined stickleback (Pungitius pungitius). J. Evol. Biol. 22(3): 544-552. doi:10.1111/j.1420-9101.2008.01674.x. PMID:19210595.

Kats, L.B., and Dill, L.M. 1998. The scent of death: chemosensory assessment of predation risk by prey animals. Ecoscience, 5: 361-394.

Kelly, C.D., Godin, J.-G.J., and Wright, J.M. 1999. Geographic variation in multiple paternity within natural populations of the 
guppy (Poecilia reticulata). Proc. R. Soc. Lond. B Biol. Sci. 266(1436): 2403-2408. doi:10.1098/rspb.1999.0938.

Kelly, J.M., Adrian, J.C., Jr., and Brown, G.E. 2006. Can the ratio of aromatic skeletons explain cross-species responses within evolutionarily conserved Ostariophysan alarm cues?: testing the purine-ratio hypothesis. Chemoecology, 16(2): 93-96. doi:10. 1007/s00049-005-0333-5.

Leduc, A.O.H.C., Noseworthy, M.K., Adrian, J.C., Jr., and Brown, G.E. 2003. Detection of conspecific and heterospecific alarm signals by juvenile pumpkinseed under weak acidic conditions. J. Fish Biol. 63(5): 1331-1336. doi:10.1046/j.1095-8649.2003. 00230.x.

Leduc, A.O.H.C., Roh, E., Breau, C., and Brown, G.E. 2007. Learned recognition of a novel odour by wild juvenile Atlantic salmon, Salmo salar, under fully natural conditions. Anim. Behav. 73(3): 471-477. doi:10.1016/j.anbehav.2006.09.005.

Leduc, A.O.H.C., Roh, E., and Brown, G.E. 2009. Effects of acid rainfall on juvenile Atlantic salmon (Salmo salar) antipredator behaviour: loss of chemical alarm function and potential survival consequences during predation. Mar. Freshw. Res. 60(12): $1223-1230$.

Lima, S.L., and Dill, L.M. 1990. Behavioral decisions made under the risk of predation: a review and prospectus. Can. J. Zool. 68(4): 619-640. doi:10.1139/z90-092.

Lima, S.L., and Steury, T.D. 2005. Perception of predation risk: the foundation of nonlethal predator-prey interactions. In Ecology of predator-prey interactions. Edited by P. Barbosa and I. Castellanos. Oxford University Press, Oxford. pp 166-188.

Magurran, A.E. 1998. Population differentiation without speciation. Philos. Trans. R. Soc. Lond. B Biol. Sci. 353(1366): 275-286. doi:10.1098/rstb.1998.0209.

Magurran, A.E. 2005. Evolutionary ecology: the Trinidadian guppy. Oxford University Press, Oxford.

Magurran, A.E., and Seghers, B.H. 1990. Population differences in predator recognition and attack cone avoidance in the guppy Poecilia reticulata. Anim. Behav. 40(3): 443-452. doi:10.1016/ S0003-3472(05)80524-X.

Magurran, A.E., and Seghers, B.H. 1994. Predator inspection behaviour covaries with schooling tendency amongst wild guppy, Poecilia reticulata, populations in Trinidad. Behaviour, 128(1-2): 121-134. doi:10.1163/156853994X00073.

Magurran, A.E., Irving, P.W., and Henderson, P.A. 1996. Is there a fish alarm pheromone? A wild study and critique. Proc. R. Soc. Lond. B Biol. Sci. 263(1376): 1551-1556. doi:10.1098/rspb. 1996.0227.

Mathis, A., and Smith, R.J.F. 1993. Chemcial alarm signals increase the survival time of fathead minnows (Pimephales promelas) during encounters with northern pike (Esox lucius). Behav. Ecol. 4(3): 260-265. doi:10.1093/beheco/4.3.260.

Mirza, R.S., and Chivers, D.P. 2001a. Are chemical alarm cues conserved within salmonid fishes? J. Chem. Ecol. 27(8): 16411655. doi:10.1023/A:1010414426082. PMID:11521402.

Mirza, R.S., and Chivers, D.P. 2001b. Chemical alarm signals enhance survival of brook charr (Salvelinus fontinalis) during encounters with predatory chain pickerel (Esox niger). Ethology, 107(11): 989-1005. doi:10.1046/j.1439-0310.2001.00729.x.

Mirza, R.S., Scott, J.J., and Chivers, D.P. 2001. Differential responses of male and female red swordtails to chemical alarm cues. J. Fish Biol. 59(3): 716-728. doi:10.1111/j.1095-8649. 2001.tb02375.x.

Nordell, S.E. 1998. The response of female guppies, Poecilia reticulata, to chemical stimuli from injured conspecifics. Environ. Biol. Fishes, 51(3): 331-338. doi:10.1023/A:1007464731444.

Owings, D.H., Coss, R.G., McKernon, D., Rowe, M.P., and Arrowood, P.C. 2001. Snake-directed antipredator behaviour of rock squirrels (Spermophilus variegates): population differences and snake species discrimination. Behaviour, 138(5): 575-595. doi:10.1163/156853901316924485.

Reznick, D., Butler, M.J., IV, Rodd, F.H., and Ross, P. 1996. Lifehistory evolution in guppies (Poecilia reticulata) 6. Differential mortality as a mechanism for natural selection. Evolution, 50(4): 1651-1660. doi:10.2307/2410901.

Reznick, D., Butler, M.J., IV, and Rodd, H. 2001. Life-history evolution in guppies. VII. The comparative ecology of high- and low-predation environments. Am. Nat. 157(2): 126-140. doi:10. 1086/318627. PMID:18707267.

Schutz, F. 1956. Vergleichende Untersuchugen über die Schreckreaktion bei Fischen unde deren Verbreitung. Z. Vgl. Physiol. 38(1-2): 84-135. doi:10.1007/BF00338623.

Smith, R.J.F. 1997. Does one result trump all others? A response to Magurran, Irving and Henderson. Proc. R. Soc. Lond. B Biol. Sci. 264(1380): 445-450. doi:10.1098/rspb.1997.0063.

Smith, R.J.F. 1999. What good is smelly stuff in the skin? Crossfunction and cross-taxa effects in fish 'alarm substances'. In Advances in chemical signals in vertebrates. Edited by R.E. Johnston, D. Müller-Schwarze, and P.W. Kluwer Academic, New York. pp 475-488.

Sokal, R.R., and Rohlf, F.J. 1995. Biometry: the principles and practice of statistics in biological research. 3rd ed. W.H. Freeman and Co., New York.

van Oosterhout, C., Joyce, D.A., Cummings, S.M., Blais, J., Barson, N.J., Ramnarine, I.W., Mohammed, R.S., Persad, N., and Cable, J. 2006. Balancing selection, random genetic drift, and genetic variation at the major histocompatibility complex in two wild populations of guppies (Poecilia reticulata). Evolution, 60(12): 2562-2574. doi:10.1554/06-286.1. PMID:17263117.

Wisenden, B.D., and Chivers, D.P. 2006. The role of public chemical information in antipredator behaviour. In Fish chemoreception. Edited by F. Ladich, S.P. Colins, P. Moller, and B.G. Kapoor. Science Publishers, Enfield, N.H. pp 259-278. 